\title{
Novel Campylobacter lari-like bacteria from humans and molluscs: description of Campylobacter peloridis sp. nov., Campylobacter lari subsp. concheus subsp. nov. and Campylobacter lari subsp. lari subsp. nov.

\author{
Lies Debruyne, ${ }^{1}$ Stephen L. W. On, ${ }^{2}$ Evie De Brandt ${ }^{1}$ and Peter Vandamme ${ }^{1}$
} \\ Correspondence \\ Lies Debruyne \\ Lies.Debruyne@UGent.be

\author{
${ }^{1}$ Department of Biochemistry, Physiology and Microbiology, Faculty of Sciences, Ghent University, \\ K. L. Ledeganckstraat 35, B-9000 Ghent, Belgium \\ Christchurch, New Zealand
} \\ ${ }^{2}$ Institute of Environmental Research and Science, Food Safety Programme, PO Box 29181 ,

\begin{abstract}
A polyphasic study was undertaken to clarify the taxonomic position of Campylobacter lari-like strains isolated from shellfish and humans. The diversity within the strain collection was initially screened by means of fluorescent amplified fragment length polymorphism analysis and wholecell protein electrophoresis, revealing the existence of two clusters distinct from $\mathrm{C}$. lari and other Campylobacter species. The divergence of these clusters was confirmed by phenotypic analysis and by $16 \mathrm{~S}$ rRNA and $h s p 60$ gene sequence analysis. Phylogenetic analysis identified C. lari, Campylobacter jejuni, Campylobacter coli and Campylobacter insulaenigrae as the closest phylogenetic neighbours of both taxa. DNA-DNA hybridizations revealed that one cluster, comprising 10 strains, represented a novel Campylobacter species, for which the name Campylobacter peloridis sp. nov. is proposed, with 2314BVA ${ }^{\top}\left(=\right.$ LMG $23910^{\top}=$ CCUG $\left.55787^{\top}\right)$ as the type strain. The second cluster, comprising six strains, represents a novel subsp. nov. is proposed, with $2897 \mathrm{R}^{\top}\left(=\mathrm{LMG} 21009^{\top}=\mathrm{CCUG} 55786^{\top}\right)$ as the type strain. The description of $C$. lari subsp. concheus has the effect of automatically creating the subspecies Campylobacter lari subsp. lari subsp. nov. (type strain LMG $8846^{\top}=$ NCTC $11352^{\top}$ ).
\end{abstract} subspecies within the species $C$. lari, for which the name Campylobacter lari subsp. concheus
}

The genus Campylobacter was created by Sebald \& Veron (1963) and has since been extended with species originating from both humans and animals. At the time of writing, the genus comprises 18 species and 6 subspecies with validly published names. Campylobacter lari was described by Benjamin et al. (1983) and has been isolated from the intestinal contents of seagulls and animals, from river water and from shellfish. In humans, strains have been isolated sporadically from diarrhoeic faeces and from cases of

Abbreviations: AFLP, amplified fragment length polymorphism; UPGMA, unweighted pair group method with arithmetic means; UPTC, ureaseproducing thermophilic Campylobacter.

The GenBank/EMBL/DDBJ accession numbers for the 16S rRNA gene sequences of strains LMG $21009^{\top}$ and LMG $23910^{\top}$ are AM922330 and $A M 922331$, respectively, and those for the $h s p 60$ gene sequences of strains LMG $22716^{\top}$, LMG $23910^{\top}$, LMG 11251, LMG $21009^{\top}$ and LMG 11760 are AM924135-AM924139, respectively.

A neighbour-joining phylogenetic tree based on $h s p 60$ gene sequences and a table of strains are available as supplementary data with the online version of this paper. bacteraemia and other extraintestinal infections, in both immunocompetent and immunodeficient patients. The species was originally referred to as the nalidixic-acid-resistant thermophilic Campylobacter (NARTC) group, but the existence of biochemical variants has been reported, including urease-producing (so-called UPTC variants), nalidixic-acidsusceptible (NASC) and urease-producing, nalidixic-acidsusceptible (UP-NASC) strains. Endtz et al. (1997) observed a striking heterogeneity amongst and within the different groups of C. lari variants; this was confirmed by Duim et al. (2004), who identified four distinct subgroups using numerical analysis of amplified fragment length polymorphism (AFLP) profiles and of partial protein profiles.

In a long-term study of the diversity of Campylobacter-like organisms, we collected C. lari-like strains from a wide range of isolation sources and geographical regions. Strain details are provided in Supplementary Table S1, available in IJSEM Online. Our aim was to study the aforementioned diversity and re-evaluate the taxonomic position of these strains, using a polyphasic approach. 
Diversity within the strain collection was initially assessed using whole-cell protein electrophoresis and AFLP analysis. Selected isolates from the observed clusters were further investigated by means of $16 \mathrm{~S}$ rRNA and $h s p 60$ gene sequence analysis and by phenotypic analysis. Finally, DNA-DNA hybridizations were performed between representatives of each novel group and closely related taxa.

Strains were grown on Mueller-Hinton agar, supplemented as necessary with $5 \%$ sterile horse blood, at $37{ }^{\circ} \mathrm{C}$ for 24-48 h, after which DNA was extracted as described by Pitcher et al. (1989).

AFLP analysis was performed as described by Duim et al. (1999). In brief, $1 \mu \mathrm{g}$ genomic DNA was digested with the HindIII-HhaI restriction enzyme combination. After digestion, site-specific adaptors were ligated to the restriction fragments. Primers complementary to the adaptor and restriction site sequence were used in subsequent pre-selective and selective PCR amplification reactions. The amplified and fluorescently labelled fragments were loaded on a denaturing polyacrylamide gel on an ABI Prism 377 automated sequencer (Applied Biosystems). GeneScan 3.1 (Applied Biosystems) was used for data collection, and the profiles generated were imported, using the CrvConv filter, in BioNumerics 4.61 (Applied Maths) for normalization and further analysis. Similarity between normalized profiles was determined using Pearson's product-moment correlation coefficient and a dendrogram was constructed using the unweighted pair group method with arithmetic means (UPGMA) algorithm. Numerical analysis differentiated two groups of C. lari-like organisms distinct from the classical C. lari and C. lari UPTC clusters, with different clusters exhibiting less than $35 \%$ similarity. The $C$. lari UPTC reference strains were selected from previous studies (Duim et al., 2004; On \& Harrington, 2000; Vandamme et al., 1991) and formed two distinct clusters, confirming previous reports on the extensive genetic diversity within this group (Matsuda et al., 2003; On \& Harrington, 2000). The taxonomy of the C. lari UPTC strains is the subject of a separate study (C. Fitzgerald, L. O. Helsel, A. Steigerwalt, P. Vandamme, J. Pruckler, M. Daneshvar, M. A. Nicholson, C. S. Harrington, P. I. Fields and S. L. W. On, unpublished results). Reference strains from Campylobacter jejuni subsp. jejuni, C. jejuni subsp. doylei, Campylobacter coli and Campylobacter insulaenigrae, the closest phylogenetic neighbours of $C$. lari on the basis of $16 \mathrm{~S}$ rRNA gene sequence analysis, could be differentiated from all $C$. larilike strains examined (Fig. 1). Clusters I $(n=10)$ and II $(n=6)$ correspond to genogroups IV and III, respectively, as described by Duim et al. (2004).

For whole-cell protein SDS-PAGE, isolates were grown on Mueller-Hinton agar supplemented with $5 \%$ sterile horse blood and incubated at $37{ }^{\circ} \mathrm{C}$ for $48 \mathrm{~h}$ under microaerobic conditions $\left(\mathrm{O}_{2} / \mathrm{CO}_{2} / \mathrm{H}_{2} / \mathrm{N}_{2}\right.$, approx. $\left.4: 6.5: 6.5: 83\right)$. The

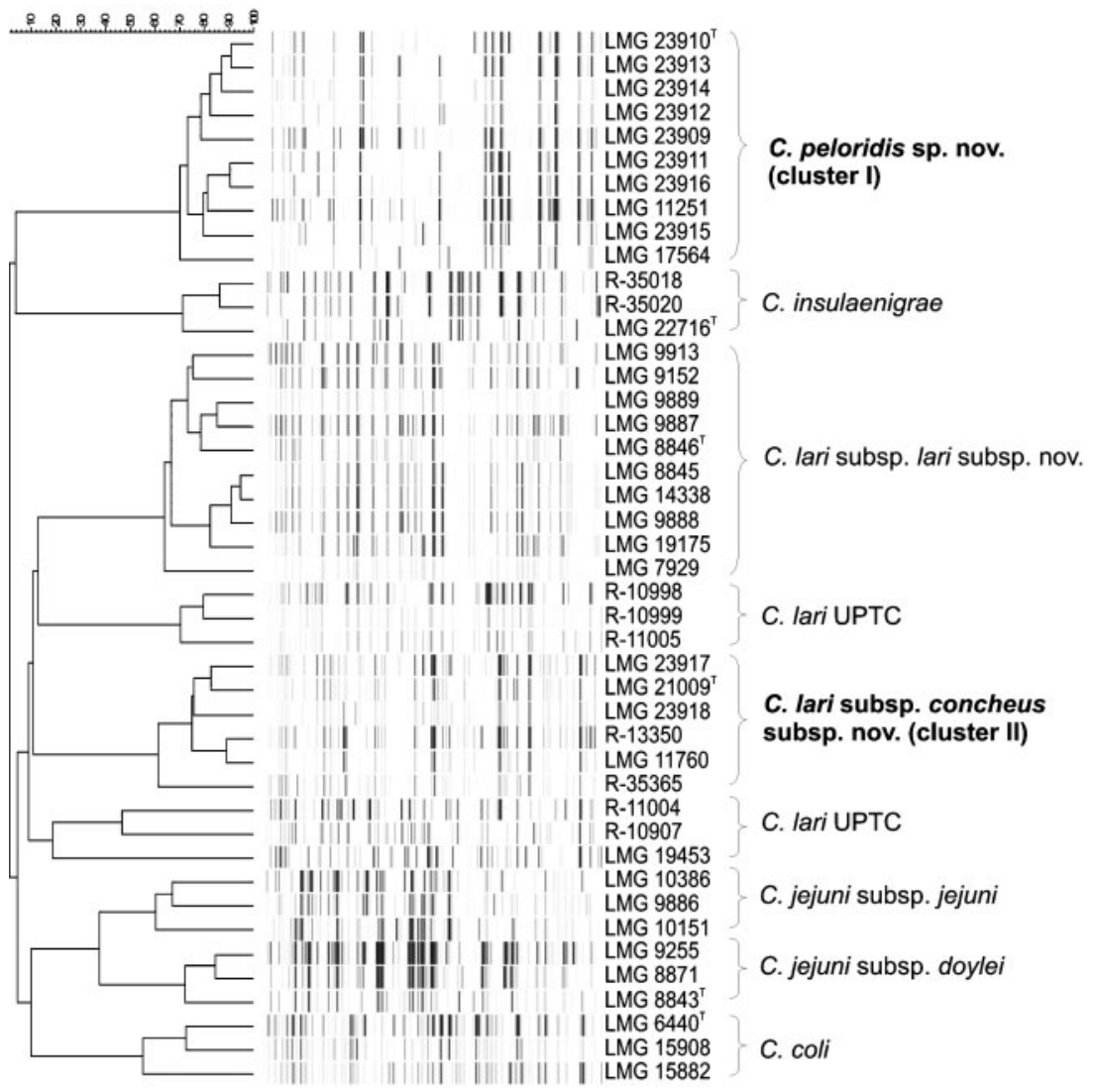

Fig. 1. UPGMA dendrogram of AFLP profiles. 
preparation of whole-cell proteins and SDS-PAGE were performed as described by Pot et al. (1994). Normalization of densitometric traces was performed using GelCompar 4.2 (Applied Maths). Numerical analysis was performed using Pearson's product-moment correlation coefficient and UPGMA with BioNumerics 4.61 software. For numerical analysis, only the region comprising approx. 20-35 kDa was used, as this part showed additional heterogeneity, which was also described by Duim et al. (2004). Cluster I, as observed in the AFLP analysis, was also observed in the protein analysis and was divergent from the classical C. lari cluster ( $83 \%$ similarity). Cluster II could also be discriminated from the classical $C$. lari cluster, but at a higher similarity level (88\%) (Fig. 2). The C. lari-like strains could also be differentiated from C. jejuni, C. coli and $C$. insulaenigrae reference strains (data not shown).

To support the delineation of the groups defined by the above genomic and proteomic analyses, phenotypic testing was performed using tests known to reveal variation among C. lari strains (On et al., 1996; S. W. L. On, unpublished results). These included evaluation of growth on media containing $2.0 \% \mathrm{NaCl}, 1.0 \%$ glycine, $0.05 \%$ safranin, nalidixic acid $\left(32 \mathrm{mg} \mathrm{l}^{-1}\right)$, cephalothin $\left(32 \mathrm{mg} \mathrm{l}^{-1}\right)$, metronidazole $\left(4 \mathrm{mg} \mathrm{l}^{-1}\right)$, carbenicillin $\left(32 \mathrm{mg} \mathrm{l}^{-1}\right)$ and $0.1 \%$ sodium deoxycholate. Growth on unsupplemented Campylobacter charcoal deoxycholate agar, growth on unsupplemented nutrient agar (no. 2; Oxoid) and the presence of urease activity were also evaluated. The methods used for biochemical testing were as described previously (On \& Holmes, 1991a, b, 1992). Characteristics that served to differentiate clusters I and II from each other and from other Campylobacter species are listed in Table 1.

The phylogenetic positions of a selection of isolates from clusters I (LMG 23910 ${ }^{\mathrm{T}}$ and LMG 11251) and II (LMG $21009^{\mathrm{T}}$ and LMG 11760) were determined by analysing almost-complete 16S rRNA gene sequences. Amplification, purification and sequencing of the 16S rRNA genes were performed as described by Vandamme et al. (2006). Sequence assembly was performed using BioNumerics 4.61 and selected sequences were aligned using CLUSTAL_X. Subsequently, the aligned sequences were imported into BioNumerics for phylogenetic analyses and bootstrap analysis (500 replicates). Ambiguous bases were discarded for the analysis and a rooted phylogenetic tree was constructed using the neighbour-joining method, with Caminibacter hydrogeniphilus $\mathrm{AM} 1116^{\mathrm{T}}$ as an outgroup (Fig. 3). The tree mainly comprises the closely related, thermotolerant Campylobacter species; a full phylogenetic tree for the genus Campylobacter was published recently (Debruyne et al., 2008). The 16S rRNA gene sequence similarity between strains LMG $23910^{\mathrm{T}}$ and LMG 11251 was $100 \%$, while that between strains LMG $21009^{\mathrm{T}}$ and LMG 11760 was $99.9 \%$. The similarity between the $16 \mathrm{~S}$ rRNA gene sequences of LMG $23910^{\mathrm{T}}$ and LMG $21009^{\mathrm{T}}$ was $97.6 \%$. Comparison with sequences available in the EMBL database indicated that, for both clusters, the closest phylogenetic neighbours (showing $>97 \%$ sequence similarity) included C. lari, C. jejuni, C. coli and C. insulaenigrae.
3.8 .8 .8

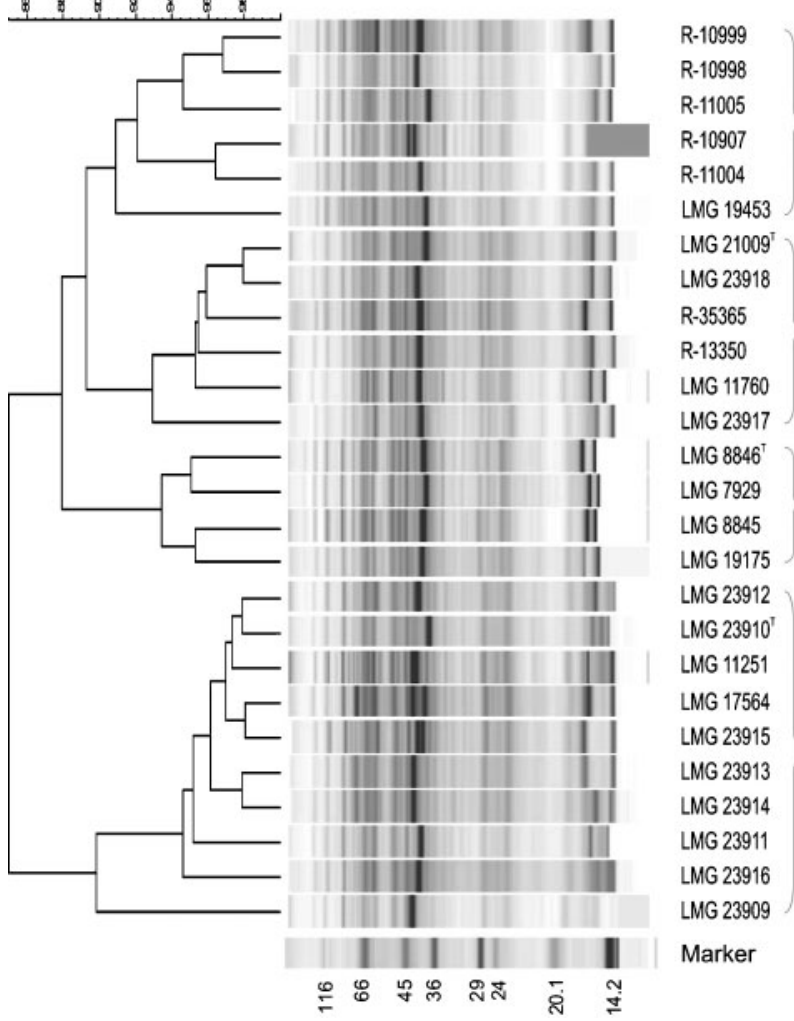

C. lari UPTC

C. lari subsp. concheus subsp. nov. (cluster II)

C. lari subsp. lari

C. peloridis sp. nov. (cluster I)

\begin{abstract}
Fig. 2. UPGMA dendrogram of partial wholecell protein SDS-PAGE profiles. The molecular mass markers used were $\beta$-galactosidase $(116 \mathrm{kDa})$, bovine serum albumin $(66 \mathrm{kDa})$, egg albumin (45 kDa), glyceraldehyde-3phosphate dehydrogenase (36 kDa), carbonic anhydrase $(29 \mathrm{kDa})$, trypsinogen $(24 \mathrm{kDa})$, trypsin inhibitor (20.1 kDa) and lysozyme (14.2 kDa).
\end{abstract}


Table 1. Differential phenotypic characteristics of the novel strains and related Campylobacter species

Taxa: 1, C. peloridis sp. nov. (cluster I; $n=10$ ); 2, C. lari subsp. concheus subsp. nov. (cluster II; $n=4$ ); 3, C. lari subsp. lari subsp. nov; 4, C. insulaenigrae; 5, C. canadensis; 6, C. coli; 7, C. concisus; 8, C. curvus; 9, C. fetus subsp. fetus; 10, C. fetus subsp. venerealis; 11, C. gracilis; 12, C. helveticus; 13, C. hyointestinalis; 14, C. hominis; 15, C. jejuni; 16, C. lanienae; 17, C. mucosalis; 18, C. rectus; 19, C. showae; 20, C. sputorum; 21, C. upsaliensis. +, All strains positive; -, all strains negative; (+), 80-94\% strains positive; (-), 5-24\% strains positive; $\mathrm{v}, 40-67 \%$ strains positive; $\mathrm{ND}$, no data available. Additional data for reference species were taken from Inglis et al. (2007), Lawson et al. (2001) and On et al. (1996).

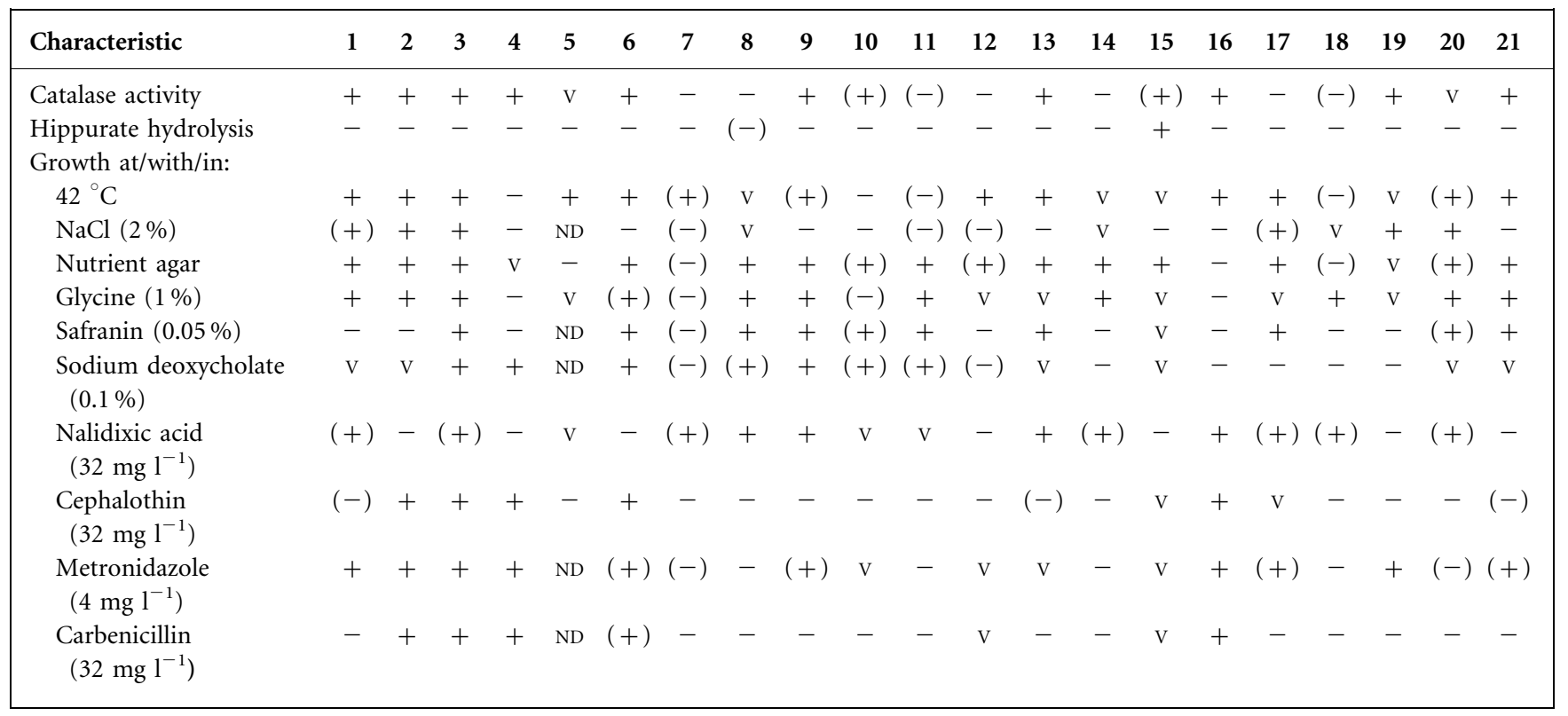

Phylogenetic relationships were further examined using sequencing of the $h s p 60$ gene (also known as cpn60 or groEL). The $h s p 60$ gene encodes the $60 \mathrm{kDa}$ chaperonin protein that is found in virtually all members of the Bacteria; the usefulness of this target for phylogenetic analysis is well established (Kärenlampi et al., 2004). Kärenlampi et al. (2004) introduced phylogenetic analysis based on the hsp60 gene for the genus Campylobacter. By cloning and sequencing a PCR-amplified fragment, they obtained a phylogenetic tree with topology similar to that of $16 \mathrm{~S}$ rRNA gene sequence-based trees, but with increased resolution due to lower interspecies similarities in the $h s p 60$ gene. The use of the $h s p 60$ gene as a phylogenetic marker for the genus Campylobacter was further optimized by the implementation of direct sequencing of PCRamplified $h s p 60$ gene sequences (Hill et al., 2006).

The reaction mixture and cycling conditions for the PCR were optimized in the present study. The PCR amplification reactions contained $1 \times$ PCR buffer, $200 \mu \mathrm{M}$ dNTPs,

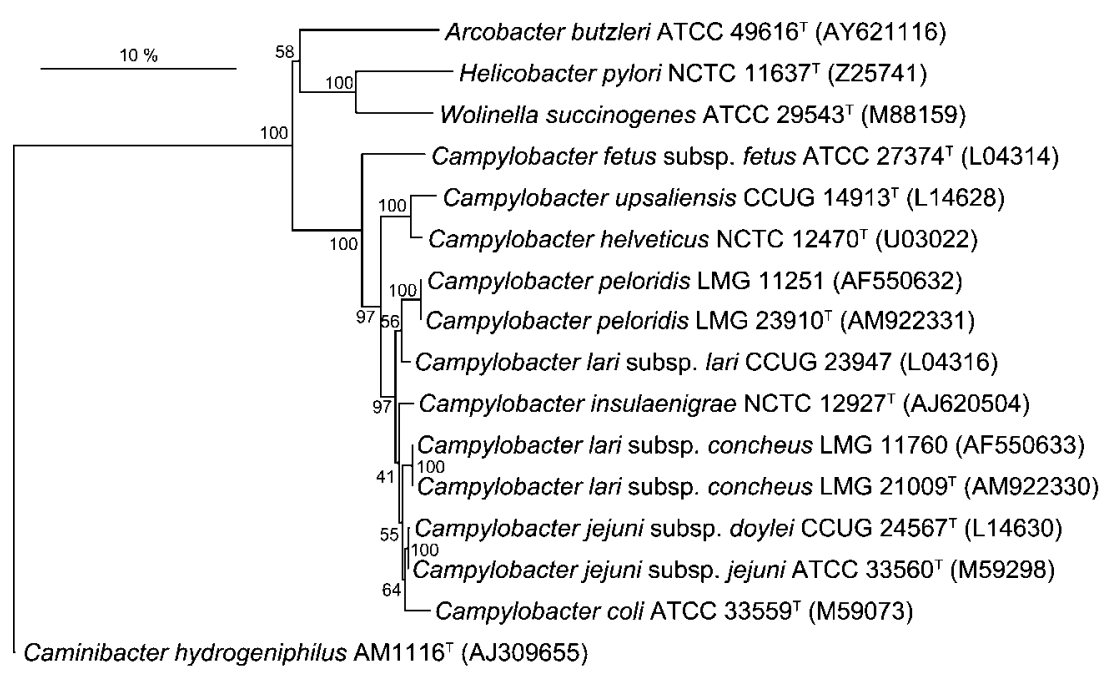

Fig. 3. Neighbour-joining phylogenetic tree, based on 16S rRNA gene sequences, for selected species. Bootstrap percentages (based on 500 replicates) are indicated at nodes. Bar, $10 \%$ sequence divergence. 
$0.5 \mathrm{U}$ Taq polymerase, 5 pmol forward primer $\mathrm{H} 729$ (5' -CGCCAGGGTTTTCCCAGTCACGACGAIIIIGCIGGIGAYGGIACIACIA-3'), 5 pmol reverse primer H730 (5' AGCGGATAACAATTTCACACAGGAYKIYKITCICCRAAICCIGGIGCYTT-3') and $25 \mathrm{ng}$ genomic DNA, with the final volume adjusted to $25 \mu \mathrm{l}$. The amplification primers include landing sites for the sequencing primers (underlined), enabling direct sequencing (Hill et al., 2006). The thermal cycling conditions were as follows: initial denaturation at $95{ }^{\circ} \mathrm{C}$ for $2 \mathrm{~min}, 30$ cycles of denaturation at $95{ }^{\circ} \mathrm{C}$ for $30 \mathrm{~s}$, annealing at $46{ }^{\circ} \mathrm{C}$ for $30 \mathrm{~s}$ and elongation at $72{ }^{\circ} \mathrm{C}$ for $30 \mathrm{~s}$ and a final elongation step at $72{ }^{\circ} \mathrm{C}$ for $5 \mathrm{~min}$. Sequencing and further analysis were performed as described for $16 \mathrm{~S}$ rRNA gene sequencing. Comparison of partial $h s p 60$ gene sequences ( $555 \mathrm{bp}$ ) with sequences in the EMBL database, using the FASTA algorithm, revealed that, for cluster I strains LMG $23910^{\mathrm{T}}$ and LMG 11251, the closest neighbour was C. lari (88-90\%). For cluster II strains LMG $21009^{\mathrm{T}}$ and LMG 11760, the closest phylogenetic neighbour was again $C$. lari, though higher similarity levels were observed (>96\%), followed by C. jejuni and C. coli $(<89 \%)$. A rooted neighbour-joining tree, with Arcobacter butzleri ATCC $49616^{\mathrm{T}}$ as an outgroup, representing the hsp60 gene sequence phylogeny, is presented in Supplementary Fig. S1.

For the determination of $\mathrm{G}+\mathrm{C}$ content, DNA was enzymically degraded into nucleosides as described by Mesbah \& Whitman (1989). The nucleoside mixture was separated using HPLC with a Waters SymmetryShield C8 column maintained at $37{ }^{\circ} \mathrm{C}$. The solvent was $0.02 \mathrm{M}$ $\left(\mathrm{NH}_{4}\right) \mathrm{H}_{2} \mathrm{PO}_{4}$ (pH 4.0) with $1.5 \%$ acetonitrile. Non-methylated $\lambda$-phage DNA (Sigma) was used as the calibration reference. The DNA G + C contents of strains LMG $23910^{\mathrm{T}}$ (cluster I) and LMG $21009^{\mathrm{T}}$ (cluster II) were 29 and $30 \mathrm{~mol} \%$, respectively. These values are within the range (29-47 mol\%) reported for the genus Campylobacter.

DNA-DNA hybridizations were performed between strains LMG $23910^{\mathrm{T}}$ (cluster I) and LMG $21009^{\mathrm{T}}$ (cluster II) and the type strains of the four most closely related species, i.e. C. lari, C. jejuni, C. coli and C. insulaenigrae, and between LMG $21009^{\mathrm{T}}$ and LMG $23910^{\mathrm{T}}$. DNA was extracted from $0.25-0.5 \mathrm{~g}$ (wet weight) cells as described by Pitcher et al. (1989). DNA-DNA hybridizations were performed with photobiotin-labelled probes in microplate wells (Ezaki et al., 1989), using an HTS7000 Bio Assay Reader (Perkin Elmer) for the fluorescence measurements. The hybridization temperature was $30{ }^{\circ} \mathrm{C}$. Reciprocal experiments were performed for every pair of strains; the standard deviations ranged from 0.8 to $9.0 \%$. DNA-DNA binding values between strain LMG $23910^{\mathrm{T}}$ (cluster I) and the type strains of C. lari (LMG $8846^{\mathrm{T}}$ ), C. jejuni (LMG $\left.8841^{\mathrm{T}}\right)$, C. coli $\left(\mathrm{LMG} 6440^{\mathrm{T}}\right.$ ) and C. insulaenigrae (LMG $22716^{\mathrm{T}}$ ) were 45, 22, 15 and $33 \%$, respectively. The DNA-DNA binding values between strain LMG $21009^{\mathrm{T}}$ (cluster II) and the type strains of C. lari, C. jejuni, C. coli and C. insulaenigrae were 78, 23, 19 and $35 \%$, respectively. The DNA-DNA binding value between LMG $23910^{\mathrm{T}}$ and LMG $21009^{\mathrm{T}}$ was $51 \%$.
For LMG $23910^{\mathrm{T}}$, the values are well below the threshold (70\%) suggested for species delineation (Stackebrandt \& Goebel, 1994), but the results for LMG $21009^{\mathrm{T}}$ and LMG $8846^{\mathrm{T}}$ indicate that these strains represent the same species. This confirms preliminary results from hybridization experiments performed between strain LMG 11760 (cluster II) and LMG $8846^{\mathrm{T}}$ (Duim et al., 2004). Both the genotypic and phenotypic analyses allowed us to distinguish these taxa from established Campylobacter species. Therefore we propose that the cluster I strains represent a novel species, for which we propose the name Campylobacter peloridis sp. nov., and that the cluster II strains represent a novel subspecies within C. lari, for which we propose the name Campylobacter lari subsp. concheus subsp. nov. With reference to data from previous studies (Benjamin et al., 1983; On et al., 1996), we correspondingly emend the species description of C. lari and propose Campylobacter lari subsp. lari subsp. nov. to encompass the classical nalidixic-acid-resistant, urease-negative isolates typified by the type strain. The divergence of the novel taxa presented here has been confirmed in previous studies, including a multilocus sequence typing system analysis (Miller et al., 2005) and a phylogenetic analysis of a partial GTPaseencoding gene (van Doorn et al., 1998).

\section{Emended description of Campylobacter lari Benjamin et al. 1984}

Cells are Gram-negative, spiral to curved rods, $0.3 \times 1.7-$ $2.4 \mu \mathrm{m}$ in size. After $72 \mathrm{~h}$ culture under microaerobic conditions on $5 \%$ blood agar, colonies are colourless, round, entire, convex and $1-1.5 \mathrm{~mm}$ in diameter. Cells show rapid darting motility by means of single bipolar flagella. Oxidase- and catalase-positive. Strains do not hydrolyse hippurate. Under microaerobic conditions, strains grow at 37 and $42{ }^{\circ} \mathrm{C}$ but not at $25^{\circ} \mathrm{C}$. No growth occurs in air at either 25 or $37{ }^{\circ} \mathrm{C}$. Acid from glucose is not detected. Growth under microaerobic conditions is observed on unsupplemented Campylobacter charcoal deoxycholate agar and on blood agar media containing $1.0 \%$ glycine, $2.0 \% \mathrm{NaCl}$ and $32 \mathrm{mg}$ carbenicillin $\mathrm{l}^{-1}$. Strains have been isolated from cases of human diarrhoea and bacteraemia, from horse intestine, from the faeces of wild birds, dogs and chickens, from environmental water samples and from shellfish.

\section{Description of Campylobacter lari subsp. lari subsp. nov.}

Campylobacter lari subsp. lari (la'ri. L. gen. n. lari of a gull).

Strains conform to the species description given above and also exhibit the following characteristics. Growth occurs on media containing $0.1 \%$ trimethylamine $\mathrm{N}$-oxide under anaerobic conditions. Strains do not grow on casein medium or on media containing $0.02 \%$ pyronin under microaerobic conditions. Urease- and DNase-negative. Nitrate is reduced. $\alpha$-Haemolysis is observed on $5 \%$ blood 
agar. Microaerobic growth occurs on unsupplemented nutrient agar, on nutrient agar media containing 0.02 or $0.05 \%$ safranin and $0.1 \%$ sodium deoxycholate and on blood agar media containing $4 \mathrm{mg}$ metronidazole $\mathrm{l}^{-1}$, $32 \mathrm{mg}$ carbenicillin $\mathrm{l}^{-1}$ and $64 \mathrm{mg}$ cefoperazone $\mathrm{l}^{-1}$. Strains have been isolated from cases of human diarrhoea and bacteraemia, from horse intestine and from the faeces of wild birds, dogs and chickens.

The type strain, LMG $8846^{\mathrm{T}}\left(=\mathrm{NCTC} 11352^{\mathrm{T}}\right)$, was isolated from gull faeces in 1976.

\section{Description of Campylobacter lari subsp. concheus subsp. nov.}

Campylobacter lari subsp. concheus (con'che.us. L. masc. adj. concheus of, or pertaining to, shellfish).

Strains conform to the species description given above. Strains of this subspecies can be distinguished from C. lari subsp. lari by their inability to grow on media containing $0.05 \%$ safranin. Growth on media containing $0.1 \%$ sodium deoxycholate is strain dependent. Pathogenicity unknown.

Strains have been isolated from human faeces and from shellfish. The type strain, $2897 \mathrm{R}^{\mathrm{T}}\left(=\mathrm{LMG} 21009^{\mathrm{T}}=\mathrm{CCUG}\right.$ $\left.55786^{\mathrm{T}}\right)$, was isolated from shellfish in 1993.

\section{Description of Campylobacter peloridis sp. nov.}

Campylobacter peloridis (pe'lo.ri.dis. L. gen. n. peloridis of a large shellfish, of the giant mussel).

Cells are slightly curved, Gram-negative rods. Colonies are colourless, round, entire, convex and $1-1.5 \mathrm{~mm}$ in diameter after culture on $5 \%$ blood agar for $72 \mathrm{~h}$ under microaerobic conditions. Oxidase- and catalase-positive. Growth occurs on media containing $1.0 \%$ glycine and $4 \mathrm{mg}$ metronidazole $\mathrm{l}^{-1}$. Most known strains (8/10) grow on media containing $2 \% \mathrm{NaCl}$ or $32 \mathrm{mg}$ nalidixic acid $\mathrm{l}^{-1}$. Most known strains (9/10) do not grow on media containing $32 \mathrm{mg}$ cephalothin $\mathrm{l}^{-1}$. Strains do not grow on media containing $0.05 \%$ safranin or $32 \mathrm{mg}$ carbenicillin $\mathrm{l}^{-1}$. Pathogenicity is unknown.

Strains have been recovered from human faeces, from dialysis fluid and from shellfish. The type strain, 2314BVA ${ }^{\mathrm{T}}$ $\left(=\mathrm{LMG} 23910^{\mathrm{T}}=\right.$ CCUG $\left.55787^{\mathrm{T}}\right)$, was isolated from shellfish in 1993.

\section{Acknowledgements}

We thank Jean Euzéby for help with the naming of the novel species, and all of the depositors of the strains listed in Supplementary Table S1. P.V. and L. D. are indebted to the Fund for Scientific Research Flanders (Belgium) for financial support.

\section{References}

Benjamin, J., Leaper, S., Owen, R. J. \& Skirrow, M. B. (1983). Description of Campylobacter laridis, a new species comprising the nalidixic acid resistant thermophilic Campylobacter (NARTC) group. Curr Microbiol 8, 231-238.

Debruyne, L., Gevers, D. \& Vandamme, P. (2008). Taxonomy of the family Campylobacteraceae. In Campylobacter, 3rd edn, pp. 3-26. Edited by I. Nachamkin, C. M. Szymanski \& M. J. Blaser. Washington, DC: American Society for Microbiology.

Duim, B., Wassenaar, T. M., Rigter, A. \& Wagenaar, J. (1999). Highresolution genotyping of Campylobacter strains isolated from poultry and humans with amplified fragment length polymorphism fingerprinting. Appl Environ Microbiol 65, 2369-2375.

Duim, B., Wagenaar, J. A., Dijkstra, J. R., Goris, J., Endtz, H. P. \& Vandamme, P. A. (2004). Identification of distinct Campylobacter lari genogroups by amplified fragment length polymorphism and protein electrophoretic profiles. Appl Environ Microbiol 70, 18-24.

Endtz, H. P., Vliegenthart, J. S., Vandamme, P., Weverink, H. W., van den Braak, N. P., Verbrugh, H. A. \& van Belkum, A. (1997). Genotypic diversity of Campylobacter lari isolated from mussels and oysters in The Netherlands. Int J Food Microbiol 34, 79-88.

Ezaki, T., Hashimoto, Y. \& Yabuuchi, E. (1989). Fluorometric deoxyribonucleic acid-deoxyribonucleic acid hybridization in microdilution wells as an alternative to membrane filter hybridization in which radioisotopes are used to determine genetic relatedness among bacterial strains. Int J Syst Bacteriol 39, 224-229.

Hill, J. E., Paccagnella, A., Law, K., Mellito, P. L., Woodward, D. L., Price, L., Leung, A. H., Ng, L. K., Hemmingsen, S. M. \& Goh, S. H. (2006). Identification of Campylobacter spp. and discrimination from Helicobacter and Arcobacter spp. by direct sequencing of PCRamplified cpn60 sequences and comparison to cpnDB, a chaperonin reference sequence database. J Med Microbiol 55, 393-399.

Inglis, G. D., Hoar, B. M., Whiteside, D. P. \& Morck, D. W. (2007). Campylobacter canadensis sp. nov., from captive whooping cranes in Canada. Int J Syst Evol Microbiol 57, 2636-2644.

Kärenlampi, R. I., Tolvanen, T. P. \& Hänninen, M. L. (2004). Phylogenetic analysis and PCR-restriction fragment length polymorphism identification of Campylobacter species based on partial groEL gene sequences. J Clin Microbiol 42, 5731-5738.

Lawson, A. J., On, S. L. W., Logan, J. M. J. \& Stanley, J. (2001). Campylobacter hominis sp. nov., from the human gastrointestinal tract. Int J Syst Evol Microbiol 51, 651-660.

Matsuda, M., Kaneko, A., Stanley, T., Millar, B. C., Miyajima, M., Murphy, P. G. \& Moore, J. E. (2003). Characterization of ureasepositive thermophilic Campylobacter subspecies by multilocus enzyme electrophoresis typing. Appl Environ Microbiol 69, 3308-3310.

Mesbah, M. \& Whitman, W. B. (1989). Measurement of deoxyguanosine/thymidine ratios in complex mixtures by high-performance liquid chromatography for determination of the mole percentage guanine + cytosine of DNA. J Chromatogr 479, 297-306.

Miller, W. G., On, S. L., Wang, G., Fontanoz, S., Lastovica, A. J. \& Mandrell, R. E. (2005). Extended multilocus sequence typing system for Campylobacter coli, C. lari, C. upsaliensis, and C. helveticus. J Clin Microbiol 43, 2315-2329.

On, S. L. W. \& Harrington, C. S. (2000). Identification of taxonomic and epidemiological relationships among Campylobacter species by numerical analysis of AFLP profiles. FEMS Microbiol Lett 193, 161169.

On, S. L. W. \& Holmes, B. (1991a). Effect of inoculum size on the phenotypic characterization of Campylobacter species. J Clin Microbiol 29, 923-926.

On, S. L. W. \& Holmes, B. (1991b). Reproducibility of tolerance tests that are useful in the identification of campylobacteria. J Clin Microbiol 29, 1785-1788. 
On, S. L. W. \& Holmes, B. (1992). Assessment of enzyme detection tests useful in identification of campylobacteria. J Clin Microbiol 30, 746-749.

On, S. L. W., Holmes, B. \& Sackin, M. J. (1996). A probability matrix for the identification of campylobacters, helicobacters and allied taxa. J Appl Bacteriol 81, 425-432.

Pitcher, D. G., Saunders, N. A. \& Owen, R. J. (1989). Rapid extraction of bacterial genomic DNA with guanidium thiocyanate. Lett Appl Microbiol 8, 151-156.

Pot, B., Vandamme, P. \& Kersters, K. (1994). Analysis of electrophoretic whole-organism protein fingerprints. In Chemical Methods in Prokaryotic Systematics, pp. 493-521. Edited by M. Goodfellow \& A. G. O’Donnell. Chichester: Wiley.

Sebald, M. \& Veron, M. (1963). Base DNA content and classification of vibrios. Ann Inst Pasteur (Paris) 105, 897-910.

Stackebrandt, E. \& Goebel, B. M. (1994). Taxonomic note: a place for DNA-DNA reassociation and 16S rRNA sequence analysis in the present species definition in bacteriology. Int J Syst Bacteriol 44, 846849.

Vandamme, P., Falsen, E., Rossau, R., Hoste, B., Segers, P., Tytgat, R. \& De Ley, J. (1991). Revision of Campylobacter, Helicobacter, and Wolinella taxonomy: emendation of generic descriptions and proposal of Arcobacter gen. nov. Int J Syst Bacteriol 41, 88-103.

Vandamme, P., Holmes, B., Bercovier, H. \& Coenye, T. (2006). Classification of Centers for Disease Control Group Eugonic Fermenter (EF)-4a and EF-4b as Neisseria animaloris sp. nov. and Neisseria zoodegmatis sp. nov., respectively. Int J Syst Evol Microbiol 56, 1801-1805.

van Doorn, L. J., Verschuuren-van Haperen, A., van Belkum, A., Endtz, H. P., Vliegenthart, J. S., Vandamme, P. \& Quint, W. G. V. (1998). Rapid identification of diverse Campylobacter lari strains isolated from mussels and oysters using a reverse hybridization line probe assay. J Appl Microbiol 84, 545-550. 